\title{
THREE CASES OF A PANCREATIC BLADDER OCCURRING IN THE DOMESTIC CAT.
}

BY

W. S. MILLER, M. D.

From the Anatomical Laboratory of the University of Wisconsin.

With 3 Text Fraures.

The arrangement of the pancreatic ducts in the cat is quite different from that in man or in the dog.

In man we find the ductus pancreaticus (Wirsungi) opening into the duodenum in connection with the ductus choledochus, while the ductus accessorius (Santorini) enters the duodenum nearer to the pylorus. The larger of these two ducts is the ductus pancreaticus.

In the dog the ductus pancreaticus, as in man, enters the duodenum with the ductus choledochus, but the ductus accessorius enters the duodenum caudosinstralward from the common opening of the ductus choledochus and ductus pancreaticus. The larger of these two is the ductus accessorius.

There are in the cat two pancreatic ducts, and their relation to the ductus choledochus and duodenum is practically the same as in the dog, with the exception that the ductus pancreaticus is the larger of the two ducts.

Following the nomenclature used by Owen, we find that the ductus pancreaticus is formed by the union of the two main trunks which come, the one from the splenic, the other from the duodorsal portion of the pancreas. The ductus accessorius is small, in some cases insignificant in size, and varies considerably in its mode of origin.

The ducts of the pancreas in Mammalia differ from those of the liver in that there is not usually connected with them a receptacle for the storage of the pancreatic juice; on the other hand, absence of a gallbladder, except in the Perissodactyla, is exceptional.

In 1815 Mayer figured and described a pancreatic bladder in a cat. This bladder was situated on the inferior (caudal) surface of the liver, close to the gall-bladder, and was connected with the duct of Wirsung AMERICaN JoURÁl OF ANaTOMY.-VOL. III. 
by means of a rather long duct. The gall-bladder occupied its usual position and exceeded the pancreatic bladder in size.

In 1879 Gage, of Cornell, figured and described a second case of a pancreatic bladder, and, like that of Mayer, it was found in a cat. This case was not mentioned by Oppel in his excellent work on the comparative anatomy and histology of the pancreas. Gage describes his case as that of a "pancreatic reservoir, analogous to the gall-bladder. In this case it is larger than the latter and partly covers it. The two are very closely bound together for about half their longitudinal extent, by a broad, firm band, which produces a decided constriction in both. The walls of the reservoir are very firm and thick, as are also those of its ducts. The duct is nearly straight, and bifurcated before terminating, sending the larger branch to the gastro-splenic division of the duct of Wirsung, and the smaller to the common trunk. . . . There was no communication whatever between the pancreatic reservoir or its duct and the gall-bladder or the ductus choledochus."

These two cases are the only authentic ones that I have been able to find in which a true pancreatic bladder has been present. It has been reported as being present in other mammals, but I fail to find substantial proof. The dilatation of the ampulla of Vater, which is often found, as for example in the elephant and rhinoceros, situated as it is within the walls of the duodenum, is quite another thing and is not to be considered a bladder.

Three cases in which a pancreatic bladder was present have come under my observation, and like the case of Mayer and of Gage, they were found in the domestic cat. Of these three cases of pancreatic bladder, cases II and III were practically identical, while case I presented quite a different type.

In case I (Fig. 1) the pancreatic bladder occupied the usual position of the gall-bladder. The gall-bladder was about one-third the size of the pancreatic bladder and was situated to the right of the pancreatic bladder, with which it was connected by a small amount of loose connective tissue. The duct leading from the pancreatic bladder crossed the ductus cysticus just as it left the gall-bladder, passed obliquely over the right branch of the ductus hepaticus, then ran parallel to the ductus choledochus, and finally joined the duodorsal division of the ductus pancreaticus $6 \mathrm{~mm}$. from its union with the splenic division. Two small ducts arising in the duodorsal portion of the pancreas joined the duct coming from the pancreatic bladder just before its union with the main duct to form the ductus pancreaticus. The lobation of the liver presented nothing abnormal; both the liver and pancreas were of normal size. 
In case II (Fig. 2) the gall-bladder occupied its usual position. The pancreatic bladder was about two-thirds the size of the gall-bladder. It occupied a position caudal to the gall-bladder, with which it was loosely united by connective tissue. The duct coming from the pancreatic bladder passed obliquely over the ductus cysticus and the right branch of the ductus hepaticus, and, after running parallel to the ductus choledochus, joined the duodorsal division of the ductus pancreaticus $11.5 \mathrm{~mm}$. from its union with the splenic division. In size the liver and pancreas were normal. The lobation of the liver was normal, except that the left lateral lobe had a deep incision extending from the porta hepatis transversely across it, nearly subdividing it into two portions.

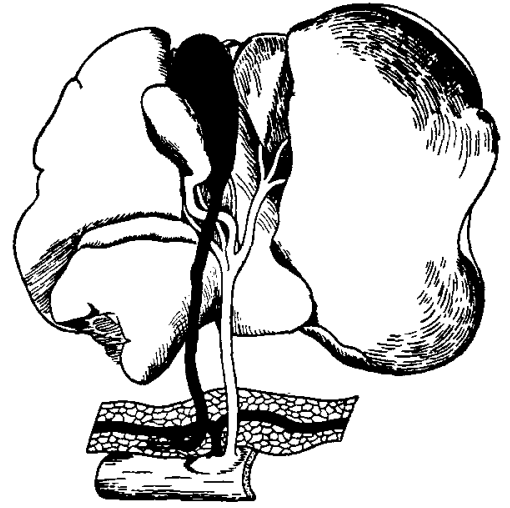

F1G. 1.

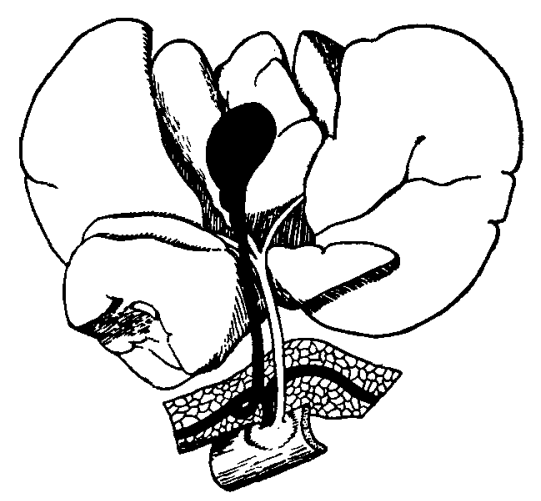

Fig. 2.

FrG. 1. Diagrammatic ontline of the liver and a portion of the pancreas and duodenum in Case I. The liver has been turned cephalad. The pancreatic ducts and blader are represented in solid black; the gall-bladder and bile ducts in outline. Note that the pancreatic bladder occupies the usual position of the gall-bladder, while the latter lies caudal to it resting on the right median lobe of the liver. The two spall ducts mentioned in the text can be seen below the point of union between the pancreatic cystic duct and the duodoreal division of the ductus pancreaticus.

FIG. 2. Diagrammatic outline of the liver and a portion of the pancreas and duodenum in Case II. The liver has been turned cephalad. Pancreatic bladder and ducts black : gallbladder and ducts in outline. The gall-bladder in this case occupies its normal position.

In case III the gall-bladder was the larger of the two and occupied its normal position. The pancreatic bladder was half the size of the gall-bladder and firmly attached to it by a strong sheet of connective tissue. The course of the duct was as in case II. It joined the duodorsal division of the ductus pancreaticus $7 \mathrm{~mm}$. from its union with the splenic division. Just before its union with the main duct of the pancreas a few small ducts coming from the adjacent part of the pancreas joined it. The left lateral lobe of the liver was somewhat folded 
upon itself, otherwise the liver showed nothing unusual; the pancreas was normal.

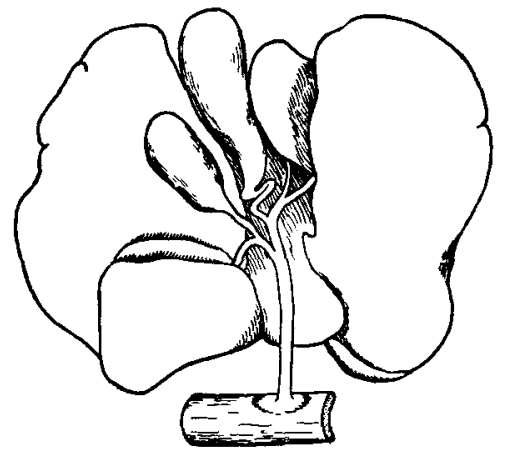

FIG. 3. Diagrammatic outline of the liver mentioned in the text in which two gall-bladders and cystic ducts were present.
It may be of interest to note that two of the above-described cases came from the same farm house and that the third came from a neighboring house. In a full brother of case II, two gall-bladders were found. There was a well-developed gall-bladder and cystic duct connected with each branch of the ductus hepaticus (Fig. 3). Of these two gall-bladders the one connected with the left branch of the ductus hepaticus was the larger and occupied the usual position of the gall-bladder, while

the one connected with the right branch was about half the size of the other and occupied a special depression on the ventrocaudal surface of the right median lobe.

The year following that in which the above-described pancreatic bladders were found, two animals were obtained from the same neighborbood, and they presented the following variations in the pancreas. In one case there was a long narrow band of pancreatic tissue extending along the ductus choledochus nearly as far as the gall-bladder; its duct joined the duodorsal division of the ductus pancreaticus. In the other case there was a duct arising from the duodorsal division of the ductus pancreaticus which ran parallel to the ductus choledochus, and in place of terminating in a bladder was connected with a small truncated mass of pancreatic tissue situated in the fossa vesicæ fellex. May not these two cases explain partially the way in which the pancreatic bladders have been formed?

All three cases of pancreatic bladder differed from those of Mayer and of Gage in that the duct coming from the pancreatic bladder joined the duodorsal division of the ductus pancreaticus.

In one case the pancreatic bladder was the larger and occupied the usual position of the gall-bladder; in the other two cases the gall-bladder was the larger and occupied its normal place.

In two cases one or more small ducts joined the duct coming from the pancreatic bladder just before it united with the duodorsal division of the ductus pancreaticus. In the third case no such branch was present. 
Mayer, A. C.-Blase für den Saft des Pancreas. Deutsches Archiv f. Physiol., Bd. I, 1815.

GAGE, S. H.-The Ampulla of Vater and the Pancreatic Ducts in the Domestic Cat. Amer. Quart. Mic. Journal, Vol. I.

OpPex, A.-Lehrbuch der vergleichenden mikroskopischen Anatomie der Wirbelthiere. Bd. III, Jena, 1900. 